\title{
In vitro Micropropagation of Talinum portulacifolium L.: An important multipurpose medicinal plant of India
}

\author{
Sanjay Kumar \\ Assit.Prof And Head, Department of Botany, Chintamani College \\ of Arts and Science, Gondpipri, Chandrapur. \\ Email: sanjaykumar.ram26@gmail.com
}

\begin{abstract}
:
The paper deals with in vitro micropropagation of Talinum portulacifolium L. ( Family: Portulacaceae) is an important multipurpose medicinal plant in the local system of medicine. It is used as a green vegetable and also as a medicine for constipation and ulcer. A low survival rate by stem cutting restricts its mass propagation. Therefore, a protocol has been developed for rapid in vitro multiplication of this plant using nodal and inter nodal region as explants. The induction of multiple shoots and roots was tried on Various media combination in laboratory. The optimum response of callus induction was achieved on MS Medium supplemented with $2 \mathrm{mg} / 1 \mathrm{NAA}$ and $0.5 \mathrm{mg} / 1$ BAP. Multiple shoot induction was achieved on MS Medium Supplemented with hormone combination $1 \mathrm{mg} / 1 \mathrm{BAP}$ and $2 \mathrm{mg} / 1 \mathrm{NAA}$ or $4 \mathrm{mg} / 1 \mathrm{BAP}$ and $1 \mathrm{mg} / 1 \mathrm{NAA}$. The healthy shoot were rooted on MS Medium supplemented with $0.2 \mathrm{mg} / 1$ IBA. The rapid in vitro multiplication will be useful in conservation and multiplication of important medicinal plant.
\end{abstract}

\section{Keywords :}

propagation, conservation, shoot multiplication, MS Medium,.

\section{Introduction:}

Plant cell have potential to differentiate on division and developed organs and complete plants (Murashige,1974). The tissue culture is actually a misnomers borrowed from the field of animal tissue culture. It is a misnomers because plant micropropagation is concerned with the whole plantlet and not just isolated tissues, though the explants may be a particular tissue (Kumar et al.,2003).Talinum portulacifolium L. is a herbs, leaves $2.0-4.5 \mathrm{X} 1.0-2.5 \mathrm{~cm}$, fleshy, obovate, flower purple in panicales, capsule 0.6-0.8 cm broad,round, seed compressed, ribbed. Flowering and fruiting occurs in the month of November to January. It is frequent on hill 
tops (Singh et al.,2000). Talinum portulacifolium, an erect under shrub belonging to family Portulacaceae, is an important medicinal plant in the local system of medicine. It grow wild in Tamil Nadu, especially in the district of Tirunelveli, Madurai and Thiruchirappalli (Nair \& Henry, 1983). It is used as a green leafy vegetable due to its rich vitamine A and mineral content. The supplementation of the leaves of this plants is reported to be better diet for strengthening the body. It is also medicine for constipation and ulcer. A low survival rate by stem cutting in

Talinum potulacifolium restricts its mass propagation via conventional methods. Therefore an efficient in vitro propagation system for producing this plant is required. Gustavsson and Stanys (2000) reported that the plants derived from tissue culture as have superior field performance to those derived from stem cutting in terms of survival rate, fruit yield, rhizome production and total plant weight.

\section{Material and methods:}

Talium portulacifolium L. plants are collected from the natural habitat and maintained in P.G.T.D. of Botany RTM NU Campus. Explants like leaf, node, inter nodes and root were collected from these plants. Explants were washed thoroughly with tap water for 30 minutes, after that explants were washed with tween 20 with vigorous shaking for 10 minutes, again they were washed in flowing tap water for 30 minutes. After that further sterilization were carried out under laminar airflow bench. Initially, explants were washed with sterile double distilled water for 5 minutes thrice. Then explants were disinfected with 0.05\% Mercuric chloride solution for 1 minutes and after that disinfected with $70 \%$ alcohol thrice for 3 minutes each and later on they were again washed with sterile double distilled water 3 times for 3 minutes each. Finally explants were trimmed into appropriate size $(0.5-1.0 \mathrm{~cm})$ and inoculated in the callus induction medium, shoot induction medium. MS medium is supplemented with different concentration of BAP, NAA, 2, 4-D. cultures were maintained at 
$25 \pm 2^{\circ} \mathrm{C}$ under a $16 / 8$-h (light/dark) photoperiod with light provided by cool-white fluorescent tube with an intensity of $80 \mu \mathrm{mol} / \mathrm{m}$ s. All media formulated were tested to determine the extent to which they promoted shoot proliferation and development. Root induction medium (MS) was supplemented with IBA in different concentration individually and in combination.

\section{Result and discussion:}

Callus induction was observed within 6-7 days of inoculation with all explants except leaf on the MS medium supplemented with NAA (2mg/1) and BAP $(0.5 \mathrm{mg} / 1)$. However, when MS medium was supplemented with 2, 4-D and Kinetin the callusing was found to be delayed and it was observed between 12-15 days depending upon the concentration of phytohormones.of all explants node and internodes were found to best explants for callus induction (Table A, Plate I). For direct multiple shoot induction explants like node and internodes, shows better response. Both node and internodes, when inoculated on MS medium supplemented with BAP (1mg/1) alone, did not develop shoots. However, when MS medium was supplemented with NAA $(2 \mathrm{mg} / 1)$ and BAP $(1 \mathrm{mg} / 1)$ it showed callus induction and multiple shoot induction simultaneously. The number of shoots was 6-7 per explants. Nodal explants inoculated on MS medium with hormone BAP $(3 \mathrm{mg} / 1)$ and NAA $(0.75 \mathrm{mg} / 1)$ induced the callus within 6-7 days of inoculation (Table B, Plate I). Callus obtained from nodal explants when sub cultured on MS medium having the combination of $\mathrm{BAP}(4 \mathrm{mg} / 1)$ and $\mathrm{NAA}(1 \mathrm{mg} / 1)$, showed the multiple shoot bud induction after 15 days of subculture. The number of shoot bud induced was in the range 8-9. After subculture on the same medium it also developed the roots (Table C, Plate I).Multiple shoot obtained were separated from parent culture and inoculated on MS medium supplemented with IBA (0.1-1mg/1). These shoots developed roots within 6-7 days of inoculation. IBA concentration $1 \mathrm{mg} / 1$ was found to be best for root initiation (Table D, Plate I). The rooted shoots transferred to a pot mixture of sterile sand and 
compost $(1: 1)$, at relative humidity $80-90 \%$, exhibited normal growth within 20-25 days.

Table A: Induction of the callus on MS medium supplemented with different hormone concentration.

\begin{tabular}{|l|c|c|c|c|l|}
\hline $\begin{array}{c}\text { Types of } \\
\text { Explants }\end{array}$ & $\begin{array}{c}\text { Medium }+ \\
\text { Hormones } \\
\text { conc.(mg/1) }\end{array}$ & $\begin{array}{c}\text { No.of } \\
\text { Explants } \\
\text { ioculated }\end{array}$ & $\begin{array}{c}\text { \% response } \\
\mathbf{\pm} \text { SE }\end{array}$ & $\begin{array}{c}\text { Duration of } \\
\text { Response(da } \\
\text { ys) }\end{array}$ & $\begin{array}{c}\text { Nature } \\
\text { Of the } \\
\text { Callus }\end{array}$ \\
\hline $\begin{array}{l}\text { Node, } \\
\text { internode, }\end{array}$ & $\begin{array}{c}\mathrm{MS}+2,4- \\
\mathrm{D}(3)\end{array}$ & 10 & $95 \pm 0.5$ & 15 & Milky \\
leaf & 10 & $85 \pm 1.0$ & 17 & white \\
\hline $\begin{array}{l}\text { Node, } \\
\text { internode, }\end{array}$ & $\mathrm{MS}+2,4-$ & 10 & $85 \pm 1.0$ & 10 & Soft friable \\
leaf & $\mathrm{D}(6)$ & 10 & $75 \pm 1.5$ & 12 & Bright \\
\hline $\begin{array}{l}\text { Node, } \\
\text { internode, }\end{array}$ & $\mathrm{MS}+\mathrm{Kn}(1)$ & 10 & - & - & Soft friable \\
leaf & $+\mathrm{BAP}(0.5)$ & 10 & $95 \pm 0.5$ & 6 & Light \\
green \\
Mof
\end{tabular}

Table B: direct multiple shooting.

\begin{tabular}{|c|c|c|c|c|c|}
\hline $\begin{array}{c}\text { Type of } \\
\text { Explants }\end{array}$ & $\begin{array}{c}\text { Medium + } \\
\text { Hormones } \\
\text { conc.(mg/1) }\end{array}$ & $\begin{array}{c}\text { No.of } \\
\text { Explants } \\
\text { ioculated }\end{array}$ & $\begin{array}{c}\text { \% } \\
\text { response } \\
\mathbf{I} \text { SE }\end{array}$ & $\begin{array}{c}\text { Duration of } \\
\text { Response(days) }\end{array}$ & $\begin{array}{c}\text { Number } \\
\text { Of the } \\
\text { shoot }\end{array}$ \\
\hline $\begin{array}{c}\text { Node } \\
\text { internode } \\
\text { Leaf }\end{array}$ & MS + BAP(3) & 10 & $95 \pm 0.5$ & $6-7$ & $7-8$ \\
\hline Node, & 10 & $85 \pm 1.0$ & $8-9$ & $6-8$ \\
internode, & MS+NAA(2) & 10 & $85 \pm 1.0$ & - & - \\
Leaf & + BAP(1) & 10 & $75 \pm 1.5$ & $10-12$ & $5-6$ \\
& 10 & - & - & $3-4$ \\
\hline
\end{tabular}

Table C: Indirect multiple shooting.

\begin{tabular}{|l|l|c|c|c|c|}
\hline $\begin{array}{l}\text { Type of } \\
\text { Explants }\end{array}$ & $\begin{array}{l}\text { Medium }+ \\
\text { Hormones } \\
\text { conc.(mg/1) }\end{array}$ & $\begin{array}{l}\text { No.of } \\
\text { Explants } \\
\text { ioculated }\end{array}$ & $\begin{array}{l}\text { \% response } \\
\mathbf{\pm} \text { SE }\end{array}$ & $\begin{array}{l}\text { Duration of } \\
\text { Response(days) }\end{array}$ & $\begin{array}{l}\text { Number } \\
\text { Of the shoot }\end{array}$ \\
\hline Node, & MS & 10 & $95 \pm 0.5$ & 15 & $7-8$ \\
internode & BAP(4)+ & 10 & $85 \pm 1.0$ & 20 & $2-3$ \\
Leaf & NAA(1) & 10 & - & - & - \\
\hline
\end{tabular}

Table D.: Root induction.

\begin{tabular}{|l|c|c|}
\hline $\begin{array}{l}\text { Medium hormone } \\
\text { Conc.(mg/1) }\end{array}$ & No. of inoculation & \% of Response \\
\hline MS+ IBA(0.1) & 5 & - \\
\hline MS+IBA(0.2) & 5 & $75 \pm 0.5$ \\
\hline MS+IBA(1.0) & 5 & $100 \pm 0.0$ \\
\hline
\end{tabular}




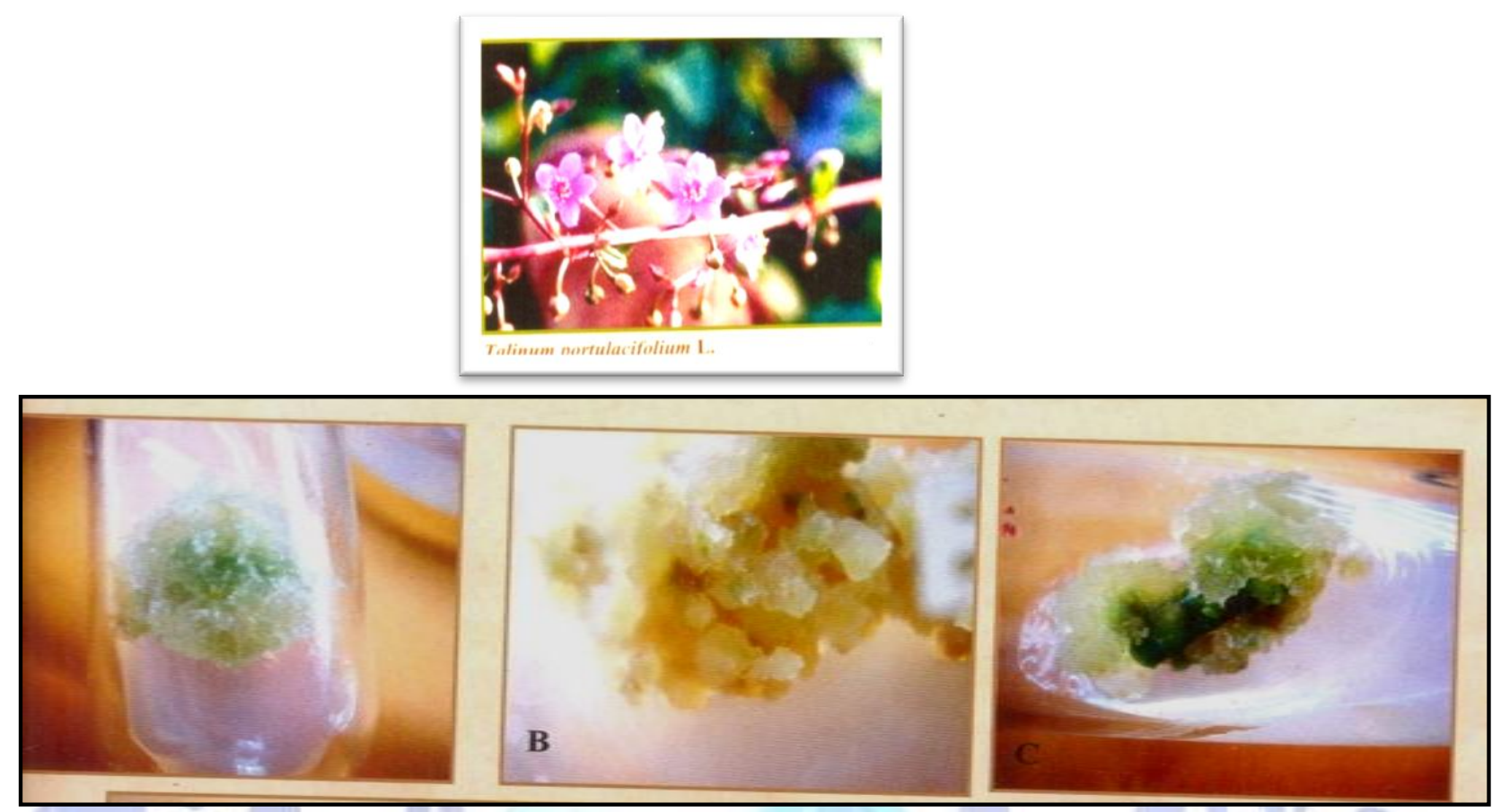

Fig. A \& B: callus induction through nodal explants, Fig. C: callus induction through intermodal explant

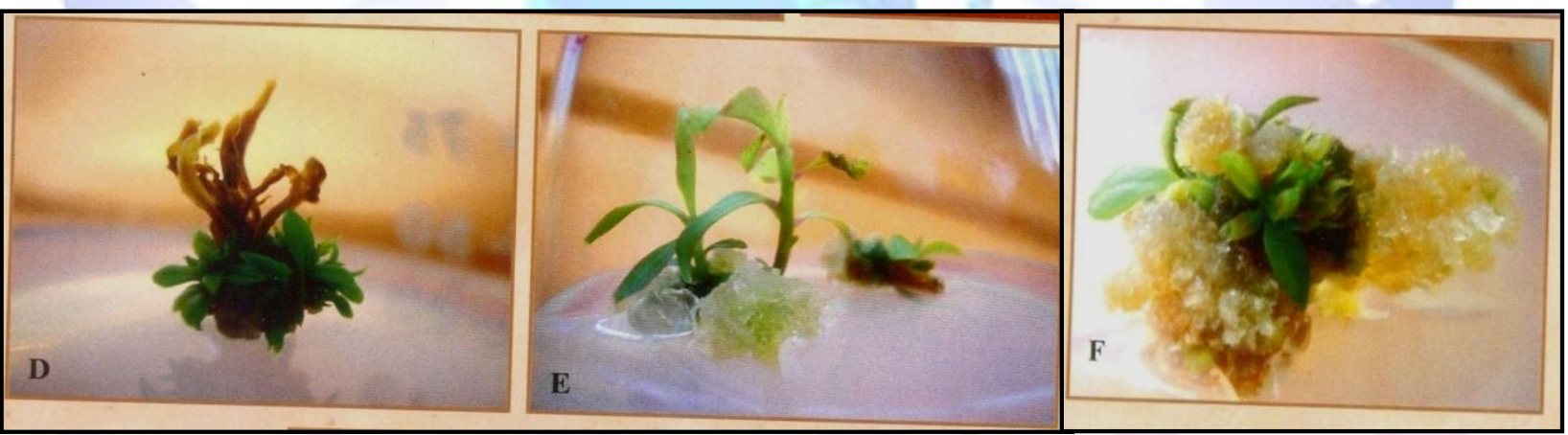

Fig.D: Direct multiple shoots induction through nodal explants,

Fig.E: direct multiple shoots induction through intermodal explants, Fig.F: Indirect multiple shoot induction through nodal callus.
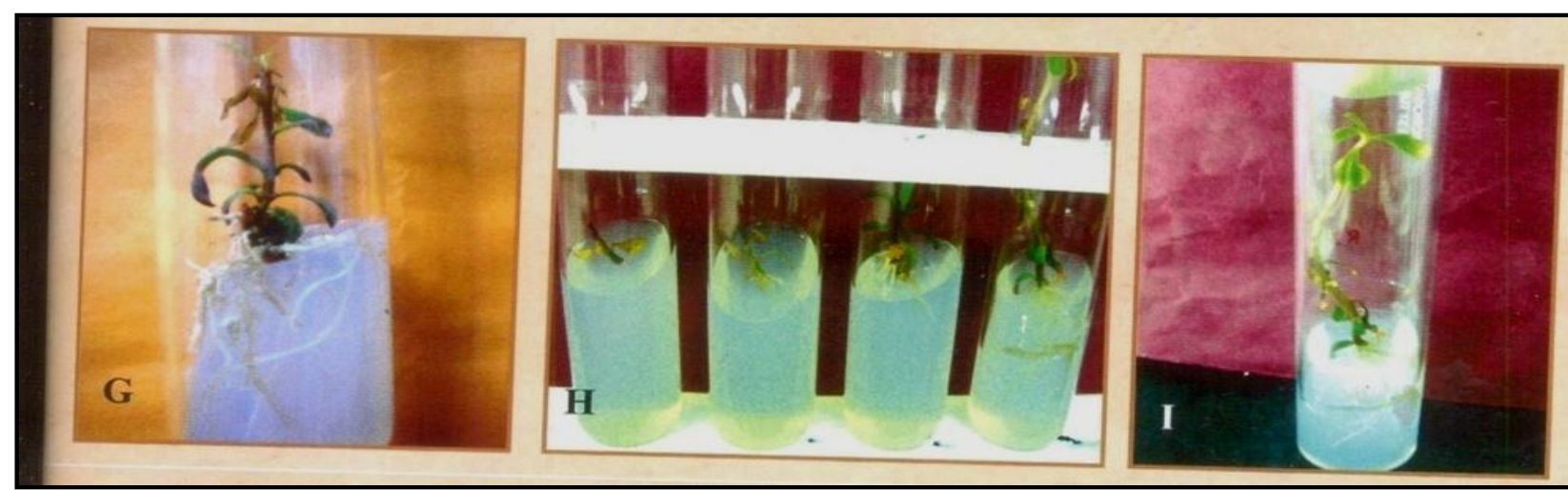
Fig.G, H \& I: Roots induction's

\section{Acknowledgement:}

My sincere gratitude to my M.Phil supervisor Dr. Arvind D.Choudhary, for giving me wonderful opportunity to work under his valuable guidance. I also proud privilege to acknowledge my indebtedness to Dr. P.B. Nandkar, Head of the department of botany, RTM Nagpur University, Nagpur for providing me all facilities in every possible manner.

\section{References:}

Gustavasson, B.A., Stanys, V. (2000). Field performance of the "sonna" lingonberry derived by micro propagation versus stem cutting. Horti. Science.35: 742-744.

Kumar , U., Sharma. A.K. (2003). Plant biotechnology and Biodiversity Conservation, Agrobios publication, Jodhpur,(India). 56-88

Murashige, T. (1974). Plant propagation through tissue culture. Annu.Rev. Plant Physiol. 25: 135-166

Nair, N. C., Henry, A. N. (1983). Flora of Tamil Nadu. Series 1 : analysis. (Botanical Survey of India). 1: 24-25

Singh, N. P. and Karthikeyan, S. (2000). Flora of Maharashtra State, Dicotyledones, BSI. Kolkata. 1 : 263-264s 